Ivanková V., Belovičová M.

\title{
Factors affecting the work of a nurse during the COVID-19 pandemic
}

\author{
St. Elizabeth University of Health and Social Sciences, Bratislava, Slovakia
}

vierkai@centrum.sk,mriab9@gmail.com

\author{
Іванкова В., Беловічкова М. \\ Фактори, що впливають на роботу медсестри \\ під час пандемії COVID-19 \\ Вища школа охорони здоров'я та соціальної роботи \\ Св. Алжбети, м. Братислава, Словаччина
}

\author{
Иванкова В., Беловичкова М. \\ Факторы, влияющие на работу медсестры \\ во время пандемии COVID-19 \\ Высшая школа здравоохранения и социальной работы \\ Св. Елизаветы, г. Братислава, Словакия
}

\section{Introduction}

The SARS-Cov-2 coronavirus pandemic in 2019-2020 is an ongoing global pandemic of COVID-19 caused by an acute respiratory syndrome called SARS-CoV-2. The virus was first reported in December 2019 in Wuhan, China, Hubei Province. The World Health Organization declared a pandemic on 11 March 2020. As of June 12, more than 7,410,510 infected patients had been confirmed in more than 216 countries or regions, with the United States, Brazil, Russia, England, Italy, and Spain being the most affected countries. The number of cured is more than 2,850,000, the number of victims is more than 418,294 . There are 1,542 infected in Slovakia as of 12 June [1].

During a pandemic and epidemic, nurses provide nursing care for critically ill and infectious patients, but there does not appear to be a systematic review of nurses' experience of working in such conditions. Nurses as the largest group of health professionals are at the forefront because they provide care to patients in close physical proximity and are directly exposed to a high risk of infection [2]. On 14 February 2020, China reported that 'SARS-CoV-2' had infected 1716 health workers, who had COVID-19. In the outbreak of SARS in Taiwan, 4 nurses died infected with the Covid-19 virus. A total of 70 health care workers deaths have been reported [3].

In many countries so far, health systems have been agile with radical and deft response to a pandemic threat. Routine procedures of elective surgery have been postponed to maintain the availability of resources for COVID19. Healthcare services have been divided into components of COVID-19 - red zones and non-COVID zones, with mechanisms for identification of patients suspected of infection and of staff among them with the aim to reduce crosscontamination [4]. These moments have a significant impact on the workforce and on the ability to provide care in times of increased need. Understanding the factors that influence aspects of nursing, as well as nurses' decisions to stay or leave the workforce, are essential for providing information about future workforce policies and about the preparedness of health systems for future epidemics/pandemics.

\section{Occupational risk perception}

The literature and our experience show that nurses are willing to accept the risks of their profession. In a pandemic situation, they perceive the risks of their work much more intensely [5]. Foreign literature reports that many nurses have decided to leave their employment due to high perceived occupational risk during an epidemic [6,7]. Regardless of the circumstances during a pandemic, nurses being often under pressure in an ever-changing and dynamic environment, perceive the risks of a pandemic as part of their role and professional responsibilities [8].

\section{Emotional state of nurses}

Not surprisingly, nurses experienced increased anxiety and concern about their own health as they have cared for infected patients during a pandemic. Concerns about their own susceptibility to infection have been largely connected with the fear of a new phenomenon with a death possibility, and it is natural that nurses feared not only the exposure to infected patients itself, but they were also concerned that the infection could spread through colleagues in the workplace. With Covid 19 confirmed positive colleagues in the workplace during a pandemic uncertainty, stress, and anxiety increased [8]. The nurses' concerns were about it being transmitted to family members, the stigma of vulnerability and restrictions on personal liberty in the case of quarantine [9]. There are known cases when nurses decided to isolate themselves from their families to protect them from transmitting the infection, especially in the case of immunocompromised family members and children [2].

\section{Communication and information}

Rapidly changing advice, information and knowledge about the infection increased the level of stress in nursing staff. As the infectious disease is new, the guidelines have been rapidly updated, often causing confusion over the most recent recommendations [10]. This confusion has also worsened nurses' fear and risk perception. Communication of information was often considered difficult rather than concise, leading to further confusion and anxiety for already busy 
nurses [2]. Misinformation is a real threat, in particular in times of crisis. Virus information from social media platforms can be easily encountered with an influx of misleading and potentially stressful information [8]. Strong leadership skills are especially important in work environments that involve high pressure situations. Head nurses assemble nurses into teams and ensure effective communication with each other, doctors, patients and patients' families. In the event of a pandemic, it is up to the head nurses to maintain morale and ensure that the teams work together to provide the best possible care to the growing number of patients.

\section{Work environment factors}

For nurses in clinical practice, the apparent impact of the pandemic concerns the psychosocial consequences. Nurses naturally experience stress associated with heavy workload and new conditions, not only during a pandemic, which can also have negative psychological impact [9]. It can also be stressful to get involved in setting up specialized pandemic red zones, triage or work outside their usual range of practice. Work and organizational readiness to cope with a pandemic is significantly influenced by the feeling of sufficiency of nursing staff. The pressure on the nursing workforce means that nurses have to adapt quickly to changes, often in suboptimal pandemic conditions, with high patient turnover and limited number of isolation rooms [8].

\section{The perception of safety}

The complexity of the nurses' situation during a pandemic may also stem from problems related to the lack of personal protective equipment, new work procedures and from the expectation of a large number of critically ill patients. As foreign authors point out [11,12], the lack of protective resources, including personal protective equipment, has contributed to the nurses' fears and to the fear of pandemics itself. The uncertainty or level of protection effective in minimizing the risk of infection provided to nursing staff, has affected the ability of many nurses to cope with the situation.

Our experience shows that regulated supplies of PPE (personal protective equipment) and their use have affected the perception of the risk of infection during a pandemic and also increased the manifestations of stress and anxiety. It is essential that nurses receive clear, concise and up-to-date information on best practices in nursing care and infection control, as well as sufficient access to appropriate PPE to optimize their safety. Adequate staffing is necessary to ensure that nurses can take breaks during work, take leave, take a so called "OČR" (providing care of a family member) or take asick leave in the event of illness [8].

\section{Conclusions}

Understanding the nurses' experience can help identify specific stressors and useful coping strategies during a pandemic. It is currently very important for creation of support systems to keep nurses in employment and to make it easier for them to provide quality healthcare. Evidence of nursing management and of a care provided for the nurses during a pandemic, recognition of the physical and emotional environment, and the ability to systematically respond to a pandemic can provide information on the current preparedness of the nursing workforce for future epidemics/pandemics. The importance of nurses and the nursing role during a pandemic and epidemic is multifaceted, and it is important that we capture the factors that influenced all its aspects in real time. To support the physical and mental health of nurses, governments, policy makers, nursing groups and health care organizations should closely monitor and respond flexibly to the needs of nurses during pandemics or epidemics as well as in the coming period through meaningful support systems. Without this support, nurses are likely to experience significant stress, anxiety, and physical side effects, all of which can lead to burnout and nurses leaving the profession. Nursing care is the largest investment in healthcare and therefore has the greatest impact on patient outcomes. In this respect, we face an extraordinary challenge to respond to a situation that has no precedent, is highly uncertain and is constantly changing in countries around the world.

\section{References}

1. World Health Organization (WHO). 2020. Rationa lmisuse of animal protection against corruption (COVID-19) and considerations for serious threats: Interim review on 6 April 2020. [online]. [cited on 2020-06-09]. Available online: https://apps.who.int/iris/bitstream/handle/10665/331695/WHO-2019 - nCov-IPC_PPE_use-2020.3-eng.pdf.

2. Fernandez, R. et al. 2020.Implications for COVID-19: systematic evaluation of nurses' experience of working in hospital acute care facilities during a respiratory pandemic. Int J Nurs Stud. 8. May 2020: 103637. doi: 10,016/ j.ijnurstu.2020.103637.

3. Lucey, D. 2020. China publishes 1,716 healthworkers with Covid-19: February 14. 2020.ScienceSpeaks: Global ID News PROJEKT IDSA GLOBAL HEALTH.

4. Zhang, Y., et al.2020. Hospital response to COVID-19: Experience in Shanghai, China. Journal of Advanced Nursing ; 2020. [online]. [cited on 2020-06-02]. Available online: https://doi.org/10.1111/jan.14364.

5. Koh, Y., Hegney, D., Drury, V. 2012. Nurses' risk perception of infectious diseases of thenurses: a study from Singapore. International Journal of Nursing Practice.2012; 18 (2): 195-204.

6. Chiang, H.,H., Chen,M.,B., Sue, I., L. 2007. Independent status of nurses in the care of survivors after SARS. Nursing ethics. 2007; 14 (1): 18-26. 
7. Martin, S.,D, Brown, L.,M., Reid, W.,M.2013. Predictors of nurses' intentions to work during the 2009 influenza A (H1N1) pandemic. AJN American Nursing Diary.2013; 113 (12): 24-31.

8. Schwerdtle, N., P., et al. 2020. Nurses' expertise: a critical resource in the COVID-19 Pandemic Response project. Annals of Global Health,86 (1), s. 49. [online]. [cited on 2020-06-02]. Dostupné na internete: http://doi.org/10.5334/aogh.2898.

9. National center for PTSD. 2020. Managing Healthcare Workers' Stress Associated with the COVID-19 Virus Outbreak [online]. [cited 2020-06-10]. Available online: https://www.ptsd.va.gov/covid/COVID_healthcare_workers.asp.

10. Houghton, C., Meskell, P., Delaney, H. et al. 2020 Obstacles and aids in complying with the Infection Prevention and Control (IPC) Guidelines for Infectious Respiratory Diseases: A Rapid Synthesis of Qualitative Evidence. Cochrane Systematic Survey Database. 2020; 4:CD013582. [online]. [cited on 2020-06-02]. Available online: https://doi.org/10.1002/ 14651858.CD013582.

11. Ives, J., et al. 2009. Attitudes of health professionals to work during pandemic influenza: a qualitative study. PublicHealth BMC.2009; 9 : 56.

12. Kang, H.S. et al. 2018. Work experience of nurses during the outbreak of respiratory syndrome in the Middle East. International Journal of Nursing Practice. 2018; 24 (5): e12664.

Дата надходження рукопису до редакції: 19.06.2020 p.

In this paper, we draw attention to factors that influenced the work of a nurse during the COVID-19 pandemic. We use special frameworks and discuss possible consequences and restrictions during the pandemic. Nurses are at the forefront because they provide care to patients in close physical proximity and are directly exposed to a high risk of infection. Regardless of the circumstances during the pandemic, the nurses perceived the risks of the pandemic as part of their role and professional responsibilities.However, they experienced increased rate of anxiety and fear for their own health when providing care to infected patients during the pandemic. Rapidly changing information and knowledge about the infection, working under pressure in dynamically changing conditions, regulated supplies of PPE and their use influenced the perception of the risk of infection during a pandemic and increased the manifestations of stress and anxiety.Evidence of the management of nurses, the impact of the physical and emotional environment, and the ability to systematically respond to a pandemic can provide information on the current readiness of the nurses' workforce for future epidemics/pandemics. The importance of nurses and the nursing role during a pandemic and epidemic is multifaceted, and it is important that we capture the factors that influenced all aspects of it in real time.

Key words: COVID-19 pandemic, first line nurses, risk of infection, physical environment, emotional environment.

У статті звертається увага на фактори, які вплинули на роботу медсестер під час пандемії COVID-19. Використано спеціальні рамки і обговорюються можливі наслідки і обмеження під час пандемії. Медсестри знаходяться на передньому плані, оскільки вони надають допомогу пацієнтам в безпосередньому близькому контакті і безпосередньо піддаються високому ризику зараження. Незалежно від обставин, під час пандемії медсестри сприймали ризики пандемії як частину своєї ролі і професійних обов'язків. Однак при наданні допомоги інфікованим пацієнтам, під час пандемії вони відчували підвищений рівень занепокоєння і страху за власне здоров'я. Швидка зміна інформації і знань про інфекцію, робота під тиском в динамічно мінливих умовах, регульовані поставки засобів індивідуального захисту і їх використання вплинули на сприйняття ризику зараження під час пандемії і посилили прояви стресу і занепокоєння. Вплив фізичної та емоційної середовища, а також здатність систематично реагувати на пандемію можуть надати інформацію про поточну готовності медсестер до майбутніх епідемій/пандемій. Значення медсестер і їх роль під час пандемії та епідемії багатогранна, і важливо, щоб ми фіксували фактори, які вплинули на всі їі аспекти в режимі реального часу.

Ключові слова: пандемія Covid-19, медсестри першої лінії, ризик зараження, фізичне середовище, емоційне середовище.

В статье обращается внимание на факторы, которые повлияли на работу медсестер во время пандемии COVID19. Использованы специальные рамки и обсуждаются возможные последствия и ограничения при пандемии. Медсестры находятся на переднем плане, поскольку они оказывают помощь пациентам в непосредственном тесном контакте и непосредственно подвергаются высокому риску заражения. Независимо от обстоятельств, во время пандемии медсестры воспринимали риски пандемии как часть своей роли и профессиональных обязанностей. Однако при оказании помощи инфицированным пациентам, во время пандемии они чувствовали повышенный уровень беспокойства и страха за собственное здоровье. Быстрая смена информации и знаний об инфекции, работа под давлением в динамично меняющихся условиях, регулируемые поставки средств индивидуальной защиты и их использование повлияли на восприятие риска заражения во время пандемии и усилили проявления стресса и беспокойства. Влияние физической и эмоциональной среды, а также способность систематически реагировать на пандемию могут предоставить информацию о текущей готовности медсестер к будущим эпидемий / пандемий. 
Значение медсестер и их роль во время пандемии и эпидемии многогранна, и важно, чтобы мы фиксировали факторы, которые повлияли на все ее аспекты в режиме реального времени.

Ключевые слова: пандемия Covid-19, медсестры первой линии, риск заражения, физическая среда, эмоциональная среда.

Конфлікт інтересів: відсутній.

Conflicts of interest: authors have no conflicts of interest to declare.

\section{Відомості про авторів}

Ivanková Viera - PhDr., St. Elizabeth University of Health and Social Sciences, Bratislava - doctoral study; Field office of bl. Metód Dominik Trčka, Michalovce, Slovakia.

vierkai@centrum.sk.

Belovičová Mária - assoc. Prof., MD. PhD, St. Elizabeth University of Health and Social Sciences, Bratislava - teacher; Field office in Michalovce a Prešov; Internal Clinic for Liver Disease Diagnosis and Treatment, Remedium s.r.o. Bardejov Spa, Slovakia. mriab9@gmail.com. 